\title{
ROMANIAN COMPULSORY MOTOR THIRD PARTY LIABILITY INSURANCE IN 2010 AND THE PREDICTABLE FUTURE
}

\author{
Marius Dan Gavriletea ${ }^{l}$ \\ Aura Carmen Moga ${ }^{2}$
}

\begin{abstract}
Insurance coverage is mandatory for the motor's owners. Analyzing the condition of the insurance market trough 2010, by the gross written insurance premiums and the losses compensations in the same period, the study analyzes the Romanian bonus-malus system, by comparing it with the bonus-malus system of other states. The study reveals the impact of bonusmalus clause, and also the impact of the economic and financial crisis upon insurance market, the insufficiencies of the MTPL system and the ways of improving it. In the last part of this study, we analyze the future changes that the insurance companies have to make in according with the elimination of the discrimination trough gender in this insurance field.
\end{abstract}

Keywords: mandatory insurance, insurance premium, Romanian bonus-malus system

JEL codes: G22, G28

\section{Introduction}

Insurance coverage for the motor's owners it is a well spread insurance product, but not all motor's owners pay the same amount for it. The differences are resulting from the tariff structure of insurance companies that have an a priori classification, where they include type and use for the car, age, gender and occupation for the policyholder, number of cars owned, rural zone, urban zone, the existence of other insurance products, and so on, as criteria's to distinguish the risks and to determine the price for the insurance. But this classification is not enough, therefore insurers also apply an a posteriori risk-classification, a bonus-malus system that reduce the premium for good drivers, and increment the payments for drivers witch produce accidents, in order to fairly distribute the burden of claims among policyholders.

Our objective is to determine the impact of the bonus-malus system, the pluses and the minuses, and the measures to be taken in the foreseeable future in order to improve the system.

The methods used to reach the objectives of the study were the analysis of the law and the directives about the bonus-malus MTPL system, the Romania MTPL market in 2010, the gross written insurance premiums and the losses compensations- compare data from 2009 and 2010, but also the comparison of the Romanian bonus-malus system with other states similar systems, critical analysis and observation, in order to determine both the weaknesses and the benefits.

\section{Compulsory MTPL and the bonus-malus system - literature review and research methodology \\ Compulsory MTPL - motor third party liability insurance is an insurance through which third parties injured following a car accident, caused by the fault of the insured, the driver shall receive compensation for damage and/or death or personal injury sustained in that accident.}

\footnotetext{
${ }^{1}$ Babes-Bolyai University of Cluj-Napoca, Faculty of Business, Romania, e-mail: dan.gavriletea@tbs.ubbcluj.ro

${ }^{2}$ Babes-Bolyai University of Cluj-Napoca, Faculty of Business, Romania, e-mail: auramoga@yahoo.com
} 
Compulsory insurance premium rates differ from society to society and, necessarily, are published on their web sites. In Romania, insurance companies set their own premium rates and notify the Insurance Supervisory Commission, but they are not subject to ISC- the Insurance Supervisory Commission approval.

The insurers may apply different correction factors (reduction or increase in the premium), according to various criteria that the insured could accomplish. After applying these own corrections, insurers are required to apply the bonus-malus system to determine insurance premiums that the insured must pay.

The topic of MTPL and the bonus-malus system was debated and analyzed in numerous articles by authors like Jean Lemaire, Hongmin $\mathrm{Zi}$, but also by Baione, Levantesi, Menzietti, Pitrebois, Denuit, Walhin and others. Lemaire began the study in 1985, in his book about automobile insurance and actuarial models, and then wrought articles about the bonus-malus systems, comparative analyses for 13 states and after that for 30 states, construction of the tariff structure, in an actuarial point of view. The comparison of BMS across countries allows countries to evaluate how "severe" their BMS is, compared to the neighbors.

The bonus-malus system is the main topic for MTPL in 2010 in Romania, because of its implementation, and also the subject for this study. We choose to analyze the Romanian market because it is a developing market, interesting for local and international insurers and MTPL because it is the most spread type of insurance in our country, with a big impact on insurer and insured.

In Romania, bonus-malus system is governed by rules issued by the Insurance Supervisory Commission and it means that the insurance that the insured / individual user will pay depends on its history for damages done in a reference period. Thus, if the policyholder falls into one of the bonus classes, the premium will be reduced and if it falls within one of the classes of malus insurance premiums will be increased.

Year 2010 is the first year of the bonus-malus system for motor third party liability insurance. Thus, insurers have submitted in the CEDAM (CEDAM is the national database of all the compulsory MTPL- motor third party liability where you can check if a motor is insured at a certain time) for all open claim files for events that happen starting January 12009 , the first year for implementing the system of bonus-malus for this insurance category.

According to to the order of the ISC number 21/2009, the bonus-malus system consists of the category basic B0, 14 bonus classes and eight classes of malus. In practice, most BMS provide a premium coefficients structure with a number of bonus classes greater than the number of malus classes, so the Romanian system follows this model too.

Class B0 is assigned to a new policyholder, without insurance history. In a few countries, the starting class in the BMS depends on exogenous variables like the age of the driver, or the annual mileage of the car.

A policyholder who did not produce damages in 2009 and ended in 2010 a policy for a period of one year obtained, because the bonus-malus a $10 \%$ reduction in the rate shown by the insurer. As CSA rules governing the existence of 14 classes of bonus, when for seven years a policyholder did not produce damages to be compensated based on car insurance, bonus granted may reach $50 \%$.

If current policy is in the class B1 through its renewal, without damage, over a period of six months it will pass in class B2. If the renewal is made on the 12 months will receive class B3. The reductions shall be granted in this way until the class B14: B0 -0\%, B1 -5\%, B2 -10\%, B3 -14\%, B4 $-18 \%$, B5 -22\%, B6 -26\%, B7 -29\%, B8 -32\%, B9 -35\%, B10 -38\%, B11 -41\%, B12 -44\%, B13$47 \%, \mathrm{~B} 14-50 \%$.

Based on his studies (Jean Lemaire and Hongmin Zi., 1994), Jean Lemaire concluded that a consequence of the implementation of the bonus-malus system is a progressive decrease of the observed average premium level, due to a concentration of policyholders in the high-discount 
classes. In the first years the premium decreases, until the best policyholders reach the highest discount; this can happen in 5 to 30 years, depending on the complexity of the bonus-malus system.

It will be interesting to determine based on a few years of implementing the system in Romania, to determine the stationary average premium level.

For an application for an insured malus / individual user are taken into account the events for which at least one claim was paid during reference under the policy held by the MTPL insurance. In such a situation, malus applies regardless of who drove his vehicle at the time of accident, and regardless of how the accident protocol (through the process report prepared by the police or by finding amicable accident). Malus clause (premium increase) applies to the number of claims produced and paid for, typically up to $200 \%$, according with the 8 classes of malus: M1 $+5 \%$, M $2+10 \%$, M3 +20\%, M4 +30\%, M5 +45\%, M6 +60\%, M7 +80\% şi M $8+100 \%$. When an insured has more vehicles, there are bonus-malus apply separately for each vehicle. Also, if disposal / deletion of an insured vehicle, to establish the new bonus-malus classes for a newly purchased vehicle, this should begin from the bonus-malus class of the insured received previously.

The bonus-malus classes, 14 for bonus and 8 for malus, are similar with the Belgian model, where there are 23 classes, but the starting level depend on the use of the car ( 85 for pleasure use and 100 for business use) aspect that doesn't exist in the Romanian system. In the case of Germany, there are exactly 22 classes, like in our system, and the starting level depends on experience and other cars in the same household. Switzerland has also 22 classes, and by introducing a penalty class for each claim is the toughest system in the world.

The countries with very simple systems have few classes of bonus-malus, like Spain 5 classes, Hong Kong and Portugal 6 classes, Kenya 7 classes, and in general are mild systems. A very complex system is the one applied in France, where you can find 351 classes, and in Norway, where there are an infinite number of classes.

In 2010, only $2 \%$ of MTPL policies concluded for individuals have been concluded with the application of a malus classe. Most of the insured persons benefited from this new system, for a reduction of $5 \%$ or $10 \%$ of the insurance premium, depending on the duration of the policy ended.

This shows that the introduction of bonus malus is a change in the benefit of the insured. But what is the negative aspect of this system? Is it all this perfect?

According with Jean Lemaire opinion, (Lemaire, et al, 1994), the bonus-malus system has two major drawbacks:

- because the malus applies regardless of the value of the claim, this determine the policyholders to bear small claims themselves, and in same cases inclusive to pay substantial amounts to their victims.

- in order to compensate the discount, the insurer should establish severe penalties, but this is against his commercial interest, and the competition in the insurance field is high.

This is the case of Romania too, where a damage of a small value determine the same malus as an important claim. That's why it can determine a conduct of dissimulating an event, by no declaring it, in order to escape the insurance penalties, even by fraud.

\section{Compulsory MTPL and fraud}

Attempted frauds have increased during the crisis, which is why ISC (Insurance Supervisory Commission) has been notified. ISC decided, with effect from 1 January 2010, MTPL insurance policy issued in the electronic system. According to the rules, issuing electronic subscription policy is defined as MTPL insurance simultaneously with the recording and storage of instant information system insurer of the data contained in the policy. This means that the insurer necessary data to be entered directly into the computer system in the policy and issue policy insured's computer system. The insurer will print half the policy paper green and half white, will present sticker while the insured has the obligation to apply it on the windshield. In this way, it is expected that human errors 
completing the policy will diminish, which will take effect and increase accuracy CEDAM national database.

Thus, the ISC has requested that vignietas be numbered, because there were fake policies issued in the name of an insurance company, but without them being issued with vignieta, without being issued by an insurer and without fulfilling the form and content conditions, the insured not being guilty that he has purchased a fake policy.

Regarding the complaints submitted to Insurance Supervisory Commission by compulsory MTPL customers, in 2010 their number was 5,300, a rate of $2.4 \%$ of cases of damage; given that insurers have opened last year more than 350,000 cases of damage and any car insurance are passed details of the Insurance Supervisory Commission. Further, the total number of claims filed, only 3083 have proved well-grounded in the law, which represents $0.9 \%$ of the approved expense records.

On the other hand, an optimal bonus-malus system would determine decreasing of fraud. A study of Baione, Levantesi, and Menzietti had designed a bonus-malus system which is adequate (a fair price to each driver) and satisfies both transparency and financial balance conditions. (Baione F., Levantesi S., Menzietti M., 2002). The system is built up based on a set of premium coefficients, considering classes' number, transition rules, starting class or level of penalization charge, but also considering claim frequency and claim severity, including a transparency condition in the model. Their model uses a Poisson distributed variable, premium coefficients sequence and transition rules to penalize drivers more heavily and to obtain a better portfolio of risks in terms of adequacy. It will be interesting to apply this kind of model to the Romanian BM system, based on a few years of implementation, to optimize the system.

\section{MTPL Romanian market- results and comments}

Another aspect changed last year in favor of the insured refers to the motors used by individuals and groups financed in lease. This category of vehicles, for compulsory motor third party liability insurance have been charged in 2010 with rates of individuals, while previously were charged with the charges for legal persons, since the machines are owned by the lease company, until the end of the lease contract and only then enter into the property of the individual who purchased the car. Thus, the owners of cars purchased in lease, until now, had to bear higher rates than in the event that would have purchased the car in a different way.

As a measure due to the financial crisis, the insurers have applied last year, in 2010, tariff reductions for motor third party liability insurance, in order to offer more easily access to the market for the clients and to come to meet their needs in a merket where the price is still a decisive factor in the decision to buy.

However, insurers have further increased approved expense reserves in the previous year's comparable rates, a fact underlined by Angela Toncescu, Insurance Supervisory Commission (CSA) President, in the National Conference on Motor Insurance. They observed a $22 \%$ increase approved loss reserve, up to 1.12 billion lei, a growth of $27 \%$ of unreported loss reserves, up from 600 million lei, the action taken by insurers to create resources cover all events that might occur in connection with such insurance. The source of this data is the CSA statistics for the year 2010. According to CSA data, in 2010 the gross indemnities paid for MTPL exceeded the amount paid in 2009, with $3.12 \%$ even tough indemnities paid for all non life class in 2010 were lower than in 2009. (table no.1). That's why the importance of MTPL for the insurers increased in 2010, the impact on theirs business including the percentage in total non life GIP, with $4.75 \%$. 
Table No. 1.

Gross indemnities paid in 2010 - non life insurance

\begin{tabular}{|l|l|l|l|l|l|}
\hline $\begin{array}{c}\text { Class of non } \\
\text { life insurance }\end{array}$ & Year 2009 & Year 2010 & $\begin{array}{c}\text { Nominal } \\
\text { Growth } \\
(\mathbf{\%})\end{array}$ & $\begin{array}{c}\text { Weight in } \\
\text { total non life } \\
\text { GIP - 2009 } \\
(\mathbf{\%})\end{array}$ & $\begin{array}{c}\text { Weight in } \\
\text { total non life } \\
\text { GIP - 2010 } \\
(\mathbf{\%})\end{array}$ \\
\hline $\begin{array}{l}\text { Motor third } \\
\text { party liability } \\
\text { insurance }\end{array}$ & $1,183,762,075$ & $1,220,703,975$ & $3.12 \%$ & $30.16 \%$ & $34.91 \%$ \\
\hline $\begin{array}{l}\text { Total non life } \\
\text { insurance }\end{array}$ & $3,925,210,870$ & $3,496,859,737$ & $-10.91 \%$ & $100 \%$ & $100 \%$ \\
\hline
\end{tabular}

Source: author based on www.csa-isc.ro/media center/ statistics

Moreover, the motor insurance market in 2010 recorded a gross written premium volume of about 5 billion lei, $10 \%$ less than in 2009, amid a decline of $25 \%$ of hull insurance underwritings for up to two, 5 billion lei, evolution actually predictable, given the huge dependence on sales of new cars and car lease. The motor third party liability insurance class recorded in 2010 (table no.2) an increase of $11,26 \%$, but the premiums- share in general insurance has increased by more than 6 percentage points to $37 \%$.

Thus, in 2010, a compulsory motor third party liability insurance generated gross written premium volume of about 2.5 billion lei, being completed more than 6.5 million contracts.

Table No. 2.

Gross written premiums in 2010 - non life insurance

\begin{tabular}{|l|l|l|l|l|l|}
\hline \multicolumn{1}{|c|}{$\begin{array}{c}\text { Class of non life } \\
\text { insurance }\end{array}$} & Year 2009 & Year 2010 & $\begin{array}{c}\text { Nominal } \\
\text { Growth } \\
\mathbf{( \% )}\end{array}$ & $\begin{array}{c}\text { Weight in } \\
\text { total non life } \\
\mathbf{G W P - 2 0 0 9} \\
\mathbf{( \% )}\end{array}$ & $\begin{array}{c}\text { Weight in } \\
\text { total non life } \\
\text { GWP - 2010 } \\
(\mathbf{\%})\end{array}$ \\
\hline $\begin{array}{l}\text { Motor third party } \\
\text { liability insurance }\end{array}$ & $2,252,065,897$ & $2,505,704,913$ & $11.26 \%$ & $31.10 \%$ & $37.41 \%$ \\
\hline $\begin{array}{l}\text { Total non life } \\
\text { insurance }\end{array}$ & $7,241,584,322$ & $6,698,511,250$ & $-7.50 \%$ & $100 \%$ & $100 \%$ \\
\hline
\end{tabular}

Source: author based on www.csa-isc.ro/media center/ statistics

\section{Limits of liability of the insurer to MTPL insurance}

MTPL Insurers are required to establish limits of liability (for compensation), which can not be lower than the limits set by current regulations issued by Insurance Supervisory Commission. The current regulations of ISC are:

- for damage to products in one and the same accident, regardless of the number of persons injured, the limit of compensation is established, to accidents produced in 2010, to a level of 500,000 euro, equivalent in lei at the National Bank of Romania exchange rate of the currency at the date of the accident. For accidents occurring in the year 2011, the limit of compensation for such risks shall be established at a level of EUR 750,000 and for accidents occurring in the year 2012, the limit of compensation for such risks shall be established at a level of 1,000,000 euro.

- for bodily injury and death, including non-patrimonial injury in one and the same accident, regardless of the number of people injured, the compensation limit is set for accidents occurring in 2010, at a level of 2.5 million euros, equivalent to foreign exchange market currency date of the accident, notified by the National Bank of Romania. For accidents occurring in 2011, the limit of compensation for these risks is set at a level of 3.5 million euros, for accidents occurring in 2012, the limit of compensation for these risks are set at a level of 5,000,000 euros. 
When the amount of damage exceeds the limits that the insurer has engaged in exchange insurance premium paid, the insurer does not cover the difference.

\section{Compulsory MTPL and gender discrimination}

Directive no. 113/2004 European Commission for the application of the principle of equal treatment between women and men regarding access to goods and services provides that, "in order to guarantee equal treatment between men and women, using gender as a factor in actuarial and statistical data" should not involve any differences in pricing and nor in providing insured benefits. In order to prevent discrimination on grounds of gender, this Directive shall apply to both direct discrimination and indirect discrimination. It might be direct discrimination only when, on grounds of sex, a person is treated less favorably than another person in a similar situation.

Until now, however, the directive allowed derogation from the rule, in Article 5 (2), provided that the insurers can use gender as a "determining factor" in the assessment of risk if they ensure that the statistics that underlie the calculations are reliable regularly updated and made available to the public. The directive did not mention for how long this exemption could continue, but require member states that chose to implement the derogation, to review their decision after five years.

Directive no. 113/2004 was taken up in the legislation of Romania, by GEO - Government Emergency Ordinance No. 61/2008, which stipulates the exemption from the provision of nondiscrimination to contracts of insurance and pension, where gender is determinant in the risk assessment, provided that the methods of calculation to be based on the actuarial and statistical data "relevant and realistic, processed, published and updated regularly ".

This year, European Court of Justice gave on March 1, the verdict in respect of gender discrimination based pricing in insurance matters. Thus, the ECJ said that after December 21's 2012, insurance companies will be prohibited from setting prices for insurance products on a risk assessment founded on statistical differences according to gender.

In the transition period of less than two years in which insurers must recalibrate their products in agreement with the new legislation, the adjustment will constitute a serious challenge for the industry profile.

Statistical data, but also other psychological and sociological studies, police reports, showed that women lead more prudent and more rarely are involved in traffic accidents than men. Since men are considered a high risk factor in accidents, the insurance premium they pay is often twice the cost of insurance paid by women.

If the calculation of prices will no longer keep account of these statistics, the price of motor third party liability insurance for women could increase in general, and for the young, to be included in the same category with the young rulers, the most risky family of drivers.

Although insurers will maintain their products at more competitive prices as possible, some companies will experience significant cost increases, with the revaluation data, and the first amendment of the terms and conditions related to policies concerned, but also necessary to promote the marketing of certain products.

\section{Conclusions}

Year 2010 is an important moment, with important impact in the insurance market. It changed the present conditions and future development of the market, nationally and internationally.

On the national ground, the introduction of bonus-malus principle in motor third party liability insurance made a difference in adjusting the insurance market in the benefit of the insured, depending on its history for damages done in a reference period. Thus, if the policyholder falls into one of the bonus classes, the premium will be reduced and if it falls within one of the classes of malus insurance premiums will be increased. 
The problem revealed by our analysis is that the extra premiums determined by penalties do not cover the bonuses for the good drivers, and that's why most likely annually the cost of the insurance will grow for all policyholders, in order to establish financial balance, in an increasing competitive insurance market. The unbalance is due to an insufficient penalty for the bad drivers, problem that can be addressed by changing the transition rules, the premium coefficients or by increasing premiums in all classes by a constant percentage.

A measure that can be taken is to distinguish the penalties based on the value of the damage. This will reduce the fraud, and increase the fairly distribution of the burden of claims among policyholders.

On the international level, from 21st December 2012, insurers will no longer be able to use gender as a factor in the calculation of premiums and benefits - an important moment for gender equality in the European Union.

The decision of the European Court of Justice produces a big change in the way the insurers price motor insurance, life and critical illness policies, annuities, private medical insurance, travel insurance and other types of cover where data shows that the sex of the insured can have an effect on the risk. Designed to correct existing discrimination, the decision may create, in turn, other discriminatory situations, relating to the impact of the judgment on premiums and benefits for policies written prior to 21st December 2012.

As further analysis, we propose to analyze this year bonus-malus system impact on premium and claims paid, in order to develop an optimal tariff structure for Romania bonus-malus MTPL insurance system, by maximizing adequacy, transparency and at the same time satisfying financial balance conditions, and also eliminating the gender factor in the calculation of premiums and benefits. For the coming years we should determine the level of efficiency of the system, comparing it with the other states systems, in order to improve it.

\section{References}

1. Baione F., Levantesi S., Menzietti M., 2002. The development of an optimal bonusmalus system, Astin Bulletin, vol. 32, no. 1, 2002, pp. 159-170

2. Lemaire J., Hongmin $\mathrm{Zi} .$, 1994. A Comparative analysis of 30 bonus-malus systems, Astin Bulletin, vol 24, no 2

3. Lemaire J., Hongmin Zi., 1994. High deductibles instead of bonus-malus. Can it work? , Astin Bulletin, vol 24, no 1

4. Pitrebois S., Denuit M., Walhin J.F., 2003. Marketing and Bonus-Malus Systems, available at http://www.secura-re.com/secura/pdf/seminars/sap-seminar-8.pdf

5. Law No. 136/1995 on insurance and reinsurance in Romania, Gazette no. 136 of the 29 December 1995 with subsequent amendments and additions

6. Romanian Government Emergency Ordinance No. 61/2008, published in Official Gazette, no. 385 of the 21 May 2008

7. Order of the Insurance Supervisory Commission number 21/2009, published in Official Gazette Part 1 no. 812 of the 27 November 2009

8. Order nr. 5/Insurance Supervisory Commission 2010 for the implementation of the rules on compulsory insurance of civil liability for damage caused by vehicle accidents, published in the Official Gazette no. 344 of the 25.05.2010

9. Directive 113/2004/European Commission

10. www.out-law.com

11. www.csa-isc.ro

12. www.allianz.ro

13. www.bcrasigurari.ro

14. www.omniasig.ro 